\title{
Application of Social Network Analysis to Accounting Researches in Private University in Ogun State Nigeria
}

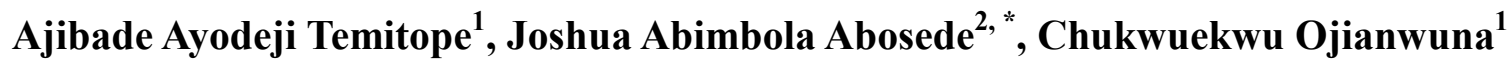 \\ ${ }^{1}$ Department of Accounting, Babcock University, Ilishan-Remo, Nigeria \\ ${ }^{2}$ Department of Accounting, Mountain Top University, Makobi Oba, Nigeria
}

Email address:

aajoshua@mtu.edu.ng (J. A. Abosede)

*Corresponding author

\section{To cite this article:}

Ajibade Ayodeji Temitope, Joshua Abimbola Abosede, Chukwuekwu Ojianwuna. Application of Social Network Analysis to Accounting Researches in Private University in Ogun State Nigeria. Journal of Finance and Accounting. Vol. 9, No. 4, 2021, pp. 127-137. doi: $10.11648 /$ j.jfa.20210904.13

Received: June 17, 2021; Accepted: July 10, 2021; Published: July 21, 2021

\begin{abstract}
Social Network analysis (SNA) is a concept that focuses on how members of a team collaborate to achieve a defined objective. The study focused on the applicability of SNA to Accounting researches in a world-class private University in Ogun State Nigeria to determine the quality of articles published in high impact journal outlet around the globe. A content analysis of publications in the google scholars of the individual researcher was conducted from the inception till date. The researchers were selected from the position of Lecturer 1 to that of the Professor using a purposive sampling technique. The data extracted was critically analysed through Social Network Analysis thereby presenting an adjacent matrix of collaborations existing among the scholars. The study also adopted a regression analysis so as to determine the extent of the impact of relationship between the researchers on their outcome. The study revealed that effective collaborations among the researchers has enhanced quality publications in high impact journal outlets around the globe which has increased both the individual global visibility as well as improvement on the University world ranking. The study as an eye opening to other private universities recommended an effective team work among the Universities researchers so as to improve quality articles publications and also for enhanced global visibility.
\end{abstract}

Keywords: Network Analysis (NA), Social Network Analysis (SNA), Accounting Research, Team Work

\section{Introduction}

Network analysis (NA) is a useful tool for planning and implementing management activities, enhances optimum resource allocation as well as ensuring completion of tasks within a stipulated timeframe [70]. The major focus of a network analysis is to establish a normal as well as minimum duration and cost. The techniques help in minimising waste and helps in advance in determining appropriate execution of activities in a complex project. Emerged from network analysis is a concept of social network analysis. Social network analysis (SNA) is a means of identifying cultural issues and providing insight into the social influences within teams. SNA focuses on analysing the connectivity existing within individuals that is how teams collaborate and how knowledge is efficiently transmitted in an organisation.
Strategically, SNA can be adopted for team development which on the long run can positively enhance changes in the dynamics of social network [72]. When a need arises to understand cultural difference among a group of people, SNA helps in providing a better insight as it unravels the social systemic aspect and not just only on individuals. The need to understand the dynamics of social organisations through the adoption of Social Network Services is becoming predominant in field of social sciences [25]. The study of social network has revealed how individual contribute significantly to their social world as there exist influence on how individual feels, interact behave and view general world [6].

Researches have tried to understand the kind of collaboration existing between author which have positively impacted on the output of their research [25]. However, more collaboration exists between the authors in applied 
sciences and engineering than that of social sciences and which reflected significant positive effect on their outcome and on the long run improves the flow of knowledge. The term social network could be referred to as the relationship either positive or negative existing within families, individuals, households, communities either rural or the urban communities. Therefore, the research organise in the field of accounting could be better served if scholars appropriately collaborate and draw upon each other's idea but worthy to note that few of such collaboration exist in social sciences [25].

Structural research is the type of research the determines link between objects of study. However, social network analysis is a structural research in social science that studies interaction among social actors which link the human beings even as far as interaction between localities such as nations, states and other foreign alliances [32]. SNA aimed at establishing the kind of pattern of social force within the individual determines the consequences of their outcome within a particular [44]. Social Network Analysis tries to establish not only the relationship existing between social actors but also set of actors. Studies have revealed that collaborations in an organisation enhances performance, positively contribute to having access to competitive advantages, achieving a sustainable competitive advantage and a powerful source of innovation [59].

The concept of network is a broad concept that can be applied to various phenomenon when a relationship can be ascribed to a set of actors as there exist patterns of ties within a collective group of individuals [78]. The pattern of ties existing within the group of actors enhance appropriate information dissemination. A research in social network helps to establish a significant relationship necessary to understand social actions as network is a set of nodes or actors such as people, organisations, teams connected by ties which varies in direction, content and strength which has significant influence on the on the network dynamism [78]. The content refers to the resources available within the network such as information, money and kinship while the direction of ties specifies contributors of resources.

It is worthy of note that values could be accorded to ties Network analysis considers two major areas of hypotheses which include those testing for relational ties within a population and those considering the consequence of the structural ties on the outcome of the individual or the population at large and powerful enough to conduct multimethod research [37, 78]. Studies have been carried out to examine the application of network analysis to determine the relationship of actors in the field of accounting, social sciences and other areas of research in international context $[6,33,44,28,37,78]$. However, this area of study is yet to be unravelled in Nigeria context which create the gap the research intends to fill. Therefore, the study aimed at determine the impact of social network in the outcome of accounting research in Nigeria by providing answer to the following research question:

To what extent is social network improving the performance of accounting researchers in Ogun State Nigeria.

\section{Literature Review}

\section{Overview of the Concept of Network Analysis and Social Network Analysis}

Network analysis (NA) is a vital technique of quantitative analysis in order to enhance an effective management decision making [32]. NA is applicable in several areas of study such as management sciences, medicine, project management, systems development, research and development, operations management and software engineering. NA enhances efficient allocation and utilization of limited resources so as to obtain the desired goal by minimising risk, ensure implementation of projects within the time frame. Massive project involving large amount of capital such as human capital, financial capital, and other resources could be easily implemented to an optimum, when network analysis is in place.

The basic design of network analysis was first introduced in the United Kingdom and in the United States of America in the mid-1950s. In 1958, Programme Evaluation and Review Technique was explored from network analysis by a team of Special Navy Project Office [32]. Generally speaking, network analysis could also be referred to and as Critical Path Analysis (CPA), Critical Path Method (CPM) and Programme Evaluation and Review Technique (PERT). Therefore, network analysis is a technique for planning and controlling so as to facilitate the management of an organisation. NA is very useful in implementing projects with identical features.

Embedded in network analysis involves both the benefits and limitations. Some of the benefits include ability to facilitate both the individual and management in planning, implementing and controlling of project processes, ability to resolve issues relating to project complexity which must be completed within a short time period. It is also useful to facilitate an effective and efficient project management and it is a simplest quantitative approach. The limitations of network analysis include the fact that only preceding activities were given due consideration and it pays attention to critical path activities of the project [32].

Social Network Analysis (SNA)

Social network analysis emerged form the concept of network analysis. Human beings are social beings that immersed in an intricate social structures as good interrelationship enhance proper human development and functioning [6]. SNA is a structural measure of properties both at individual level, general, dyad, triad and subnetwork [19]. Studies revealed that human being impact on each other by the structures of social world. According to [69], SNA is a collection of methods and tools that could be used to study relationship, interactions and communications which could be implemented through visualisation and mathematical analysis. Through visualisation, SNA presents the relationship between the social actors through graphs which 
is rooted in the mathematical graph theory indicated by nodes (actors) and edges (arrows indicating relationship).

SNA reveals in the interactions of social actors both active and isolated actors, the kind of group that is densely or sparsely interacted. The mathematical analysis of SNA involves the use of graphs for the calculation of metrics representing links, nodes or the network. The metrics are important parameters quantifying interactions between the actors and the frequency of the interactions [69]. Centrality scores represent the parameters for actors such as roles and position in the exchange of information. The study of network can be carried out either through sociocentric which is a complete study of complete network which is the complete picture of actors' connection on the network [56] or through egocentric which is the study of ego-network [19].
SNA mixes both quantitative and qualitative method of study since network can both be structured and processed at the same time which can therefore evade simple categorisation as either quantitative or qualitative. Also, SNA put into consideration the perception of people as regards the network, the content and the meaning of ties which is essential to the understanding of network patterns and measures. When both the quantitative and qualitative methods are combined in the SNA, it gives a broader and complete view of interactions among the actors. However, adopting only the quantitative method is seen as unidimensional and more restrictive as qualitative data gives room for bifocal approach to network analysis and helps in the interpretation of network diagrams and measures.

Examples of individual interactions represented diagrammatically using SNA.

Table 1. Elements of Social Network.

\begin{tabular}{|c|c|c|}
\hline \multicolumn{3}{|l|}{ Size } \\
\hline $\begin{array}{l}\text { Nodes represent the number of people in } \\
\text { the network. }\end{array}$ & Size of the network & Number of individuals in the network \\
\hline $\begin{array}{l}\text { Number of links - social } \\
\text { connections/relationships between nodes } \\
\text { (e.g. friendship, family ties) }\end{array}$ & How 'busy' the network in total & $\begin{array}{l}\text { Number of relationships between individuals in the } \\
\text { network (in total) }\end{array}$ \\
\hline Number of unique links & $\begin{array}{l}\text { How 'busy' the network is, taking out relationships } \\
\text { that are duplicated }\end{array}$ & $\begin{array}{l}\text { Number of relationships between individuals in the } \\
\text { network, with duplicates removed }\end{array}$ \\
\hline $\begin{array}{l}\text { Number of components - distinct groups } \\
\text { in the network }\end{array}$ & Whether there may be sub-groups in the network & Number of discrete groups in the network \\
\hline Density & $\begin{array}{l}\text { The extent to which nodes are interconnected - lower } \\
\text { density networks have fewer links between nodes }\end{array}$ & The proportion of all links that are actually present \\
\hline Diameter & Size of the network & Greatest number of steps between any pair of nodes \\
\hline Mean average distance between nodes & $\begin{array}{l}\text { How 'close' (in network terms) the nodes are to each } \\
\text { other }\end{array}$ & $\begin{array}{l}\text { Average number of steps needed to go from one node to } \\
\text { any other }\end{array}$ \\
\hline Mean degree & How central (on average) nodes in the network are & Average number of links that pass through the nodes \\
\hline Mean betweenness & How central (on average) nodes in the network are & Average number of unique paths that pass through the nodes \\
\hline
\end{tabular}

Open Government Licence, (2016).

\subsection{Empirical Review}

\subsubsection{Social Network Collaborations - Evidence from Accounting and Management Research}

There are few extant literatures that provide evidence about collaborative networks among researches in Accounting and management sciences and generally in the applied sciences. For example, the study of [58] observed that the mean number of authors per article has improved across all discipline in accounting and management sciences. The increase witnessed in the field of management among the co-authors was occasioned by the need to harmonize skills and expected increase the level of acceptance of manuscript as enunciated by [50]. Study regarding gender inequalities has not provided conclusive evidence. The study carried out by [61] observed that, between 2008 and 2003, only 2 percent of female authors signed papers in high impact journals in the field of operations research and management sciences out of the sampled 33 percent. Contrariwise, [17] opined that topmost male researchers in the field of public administration were more possible than their female counterparts to publish sole-authored articles and those female authors have the likelihood to have their papers published in high impact journals, which indicates that they derive benefit from the extent of significance to publish high quality and research that has impact. The seminal work of [57] indicated that the share of women in authorship was significantly lesser than men, though, disparities in the rate of quotations seemed to be infinitesimal vis- a-vis the sample of 65,436 writers in the field management research. [1] observed that the networks achieved from publishing in some prominent journals of American and European devoted to administrative studies were comparatively consistent and that noticeable places were being filled up by writers who played a critical role in linking the network and distributing information. [7] opined that, while defined writers, organizations and nations rated highly in respect of direct networks, others were involved in very essential functions as doorkeepers and bridging the gaps in the network. Writers that have more publications and more considerable have the tendency to have more connectivity via numerous direct 
connections. As per the accounting profession, [26] noted a material inverse association between a scholar's section of co-authored publications and his or her work product. According to [47] it was noted that there was an improvement in global alliances in the journal of Strategic Management for the period between 1980 and 2014. Investigation revealed further improvement in the compactness and interconnectivity and a reduction in disintegration, demonstrating that the network was in the verge of aggregation. Findings also revealed that while limited organizations indicated less level of centrality significance, they had great relationship ratings. Organizations situated in lesser and emerging or emergent nations are inclined to demonstrate global alliance with organizations situated in advanced nations to advance and participate in the relationship/network. Similarly, [65] suggested that papers published via international partnership in Latin American and Caribbean research in the field of accounting was 1.59 times greater impact than those published via local cooperation. [29] in Brazil, suggested that the growing setbacks in publishing in an impactful journal with high quality and the view of force to publish, had persuaded the scientific partnership in the field of accounting. Research has shown an improvement in the proportion of co-authored research work [27], a greater degree of Network hegemony enquiry 211 disintegration in the linkage [20] as well as a preponderance of a well specified arrangement linked through limited mediators [66]. Furthermore, a good number of co-authors have its place in the organization [27], of which it is disturbing, once networks that are heterogeneous in nature were cause in accomplishing improved scientific invention in schools that are business inclined [60]. According to [66] it was argued that the where Brazilian institutions are situated are material to consider in the establishments of common relationships. As regards of geography, the organizations in the southern and southeast of the nation are outstanding [27, 73, 77]. Therefore, we underscore the significance of bearing in mind terrestrial distinctiveness in the investigation of association network in Brazil, as the Brazilian scientific construction is not correspondingly dispersed.

\subsubsection{Social Network Collaboration - Evidence from Accounting and Auditing Practice}

Studies in this area mainly focus on whether clients of the same audit firm, local office, or partner share common characteristics and whether auditor ties and social capital increase audit quality. The primary paradigm among these studies is contagion (five studies), followed by capitalization and convergence (four studies each), and cooperation (one study). Generally, auditors play a monitoring role that is influenced by individual expertise, independence from the client, and reputation in a marketplace for audit services, among other factors [24]. If connections between clients of the same auditor facilitate the transfer of expertise and increase auditors' social capital, connections should have a positive effect on audit quality [9]. However, there are four cases in which connections may have a detrimental effect on the audit environment. First, connections may threaten independence, especially when auditors are appointed based on their social ties with management or with the board [36, 39]. Second, by construction, auditors connected to a large number of clients also have a large market share and they can use their position in the network to extract rents (i.e., high pricing power, as in [10]. Third, connections may facilitate an undesired spillover of proprietary client information [4]. Finally, connections may also enable the transfer of bad practices between clients of the same firm or office [30]. Regarding the structure of the network, most of these studies view companies as nodes and shared auditors as connections. As more granular data became available, the audit literature moved from audit firms (e.g., Big $\mathrm{N}$ versus non-Big $\mathrm{N}$ ) to local practice offices and, more recently, to audit partners. U.S. studies typically rely on Audit Analytics to obtain audit firm information and some non-U.S. studies have access to audit partner information. There is considerable variation in the strength of auditor ties. The strongest tie is arguably between two clients that share the same audit partner. The weakest tie is between two clients of the same audit firm (i.e., possibly audited by different local offices and partners). The majority of studies in this area assume that knowledge spillover occurs across and within offices of the same auditor. Specifically, auditor ties result in the contagion of lowquality practices [30] local offices experience reputation spillovers within their network of clients [31] and, two clients may mitigate the risk of proprietary information leakage by hiring different auditors [4]. Some recent studies provide preliminary evidence based on the convergence and capitalization paradigms. Small firms that are members of an accounting association network have comparatively higher quality and charge higher audit fees [11]. Moreover, the size of an individual auditor's network is linked to audit quality, audit fees, and the transfer of tax expertise between clients $[9,10]$. However, social ties between auditors and audit committee members are detrimental to audit quality, potentially due to a loss of auditor independence $[39,21]$

Finally, a relatively unexplored issue is whether the cooperation paradigm affects auditors' social capital and in turn increases audit quality and fees [42]. We envision future research opportunities on auditing in these directions: (1) the role of networks in facilitating knowledge spillover within audit firms, offices, and teams remains an open empirical question [15]; (2) the role of social ties, and strength of ties in transferring complex and tacit knowledge across audit and consulting units (e.g., tax advisory) within an audit firm; (3) the effect of ties between individual auditors and client personnel on trust and information acquisition; (4) implementing insights from research on cliques, clusters, and blocks to examine how audit team structure affects communication, knowledge sharing and team level audit outcomes; (5) ties between internal auditors and external auditors, and internal auditors and other employees within an organization; (6) whether closed networks or structural holes networks are more beneficial for audit quality; (7) partner 
names and component auditor information have recently become available in the U.S. through the PCAOB Form AP, enabling future research examining this data; (8) the insights from auditing studies may inform other research on similar professional networks, such as law firm connections [23].

Social Network Theory is the study of how people, organizations or groups interact with others inside their network. Understanding the theory is easier when you examine the individual pieces starting with the largest element, which is networks, and working down to the smallest element, which is the actors.

\subsubsection{Social Network Collaboration - Evidence from Universities and Tertiary Institutions}

According to [8], Universities and similar institutions of higher learning encourage improvement by the establishment and transmission of essential talents and know-how to the average man. Generally, universities comprise of societies of academia saddled with the responsibilities of fostering the unrestricted flow, attainment, distribution, and transmission of evidence and information [67, 38, 5]. Furthermore, these scholars noted that in the past, universities had always been the keepers of communal legacy through the safeguarding, fine-tuning, recording and dissemination of societal mores, values, principles and know-hows for generations to come.

According to [64] sharing of knowledge is a common method relating two or more persons who segment and improve their skill, and value from each other's treasure of knowledge. There are many computer-generated media that simplify evidence and information distribution, and even more types of evidence and information that can be pooled together. In a community that is focused on information, the achievement or letdown of our everyday undertakings is intensely influenced by how up-to-date we are throughout their implementation; degrees of accomplishment can be enhanced through allocation. As posited by [14] the universal movement and knowledge sharing improves research and development in all spheres, enabled by the collaboration and association of researchers. Similarly, [55] observed that sharing of information and knowledge tends to acquaintance with others in similar endeavours. According to [34] he posited that in the event that you have the ability and willingness to share information among the members of your group, you can be deemed to be in a prominent position in the group. Furthermore, another fascinating characteristic of information and knowledge sharing as enunciated by [56] is that the ecosphere of scientific groups is lesser; there are no obstacles regarding the time and terrestrial locality. Researchers therefore have the edge of being effective in networking and dissemination of findings from the research.

In the science literature, it is a general phenomenon to share information and knowledge through consultation. Writers like [3] demonstrated the importance of scholars' involvement network communication. Some scholars have come up with their own concepts. According to [18], for instance, established the theory of virtual colleges, and demonstrated that the most fruitful participants in these networks have more communal bonds, impact, and conspicuousness in comparison with those that are less involved. According to [48] and [74], amongst others, established that the degree of collaborations and links a researcher has with other scholars is the most robust determinant of their efficiency in publication. However, [74] and [12] observed that, communication of information and knowledge sharing have a positive relationship with apparent separate efficiency and project output and performance. The interaction stated may also be virtual and not necessarily physical contacts. Review of extant literature is also an integral contact among the researchers.

Information technology can improve information sharing among the universities. ICTs are beneficial in knowledge administration, which comprises information storage, processing, and distribution [2, 43] describes the worth of ICTs such as web portals in linking scholars for the distribution of thoughts, particularly in a university system and further espoused the importance of ICTs in enhancing knowledge sharing in universities and other higher institutions of learning. In the study carried out by [68], it was revealed that the majority of the surveyed academics in both countries used computers, mobile telephony, social media, and the internet.

\subsection{Theoretical Review}

The Social Network Theory examines the interrelationships amongst people, institutions and group in their social networks. Selected theories are examined in this study

\subsubsection{Mutual-interest and Collective Action Theory}

In social network studies, one major reason for people to form relations is self-interest, i.e., to make the most of their personal inclinations and yearnings [16]. However, when involved in a social group, individual interests are constrained by the interdependent relationship with others. Social relationships impose some restrictions on both participants' and controls the level of egocentric [45]. Mutual interest becomes the objective people need to maintain. Collective action theory focuses on shared interests and the likelihood of assistances from harmonized accomplishment [53]. In a recommender system setting, this relates to a group of people forming a unified opinion on products. Previous research found that being in a social group affects the intensity and opinion of people involved in social issues discussions [46]. This theory was used to examine implementation of revolutions in group of people/organization [51, 62] where individuals' adoption decisions depend on the decisions of others [63].

\subsubsection{Cognitive Consistency Theory}

Cognitive consistency theory major focus is on the cognition of members in relation to other members of the groups' opinions. At the dyad level, Heider's balance theory suggested that if two persons were friends, they should have comparable assessments of an objective [40]. If the individuals have inconsistent opinions, they would go all-out 
to minimize this cognitive discrepancy by changing their opinions or their friendship. Cognitive consistency theories seek to explain the need for consistency at a higher network level. If the group has more than 2 members, this requirement is more distinctive. In an organizational behavior context [13]. argue that the addition of a third party will act as a key limitation on behavior compared to when there are only two weakly connected actors [13]. Freeman proposed that consistency theories lend itself to a methodical description for dissimilarities between real and self-reported communication information [32].

\subsubsection{Homophily Theory}

Theory of Homophily examines how the resemblance between persons affects the way they behave Prior literature on homophily tested its role in allowing the development of communal associations and its consequence on relation power [52, 54]. Homophily could also affect a receiver's probability of accepting instruction. In the recent past, literature relating to marketing has positioned homophily focus platform and established its considerable consequence on a receiver's enthusiasm to receive a basis's approvals [22, $35,49]$ differentiated two categories of homophily: status homophily, in which resemblance is founded on casual, official, or attributed position, and value homophily, which is grounded on values, mores and attitudes. Status homophily comprises the demographic proportions, such as community society attributed features such as race, ethnicity, gender, or age, and assimilated features similar to religion, education, occupation, or behaviorial patterns. Value homophily embraces the extensive diversity of in-house situations acknowledged to form our alignment in the direction of upcoming actions [54], which can be taken from persons' prerogatives.

\subsubsection{Social Identity Theory}

The theory of social identity proposes that when people view themselves as memberships of a group, they recognize with that group and subordinate themselves with its characteristics and standards Social identity involves a consciousness of be in the right place to a certain association and appreciating that group membership. That uniqueness is preserved and improved through discerning changes among one's group and other groups, and making judgements that benefit ones' group [76]. The fundamental incentive is realized as the necessity for an optimistic self-respect [41].

\subsection{Theoretical Framework}

This study will be hinged on Mutual-interest and Collective Action Theory. Collective action theory emphases on mutual interests and the likelihood of assistances from synchronized accomplishment [53]. When people and/or group are involved in a social group, individual interests are constrained by the interdependent relationship with others. Social relationships impose restrictions on both actors' behavior and controls the level of self-centered [45]. In the field of accounting, particularly in academia, like
Universities, mutual interest and collective action would bring about high-quality work product in academic research.

\section{Methodology}

The study analysed the collaboration of Accounting authors in their various local University journal in the field of Accounting. The Accounting researchers of a world-class private University in Ogun State was critically examined. The study aimed at determining how collaboration between the accounting authors in the University under consideration has helped in producing articles in high impact journals. Articles were linked to the names of the respective authors and the co-authors which was done through an exhaustive manual checking. The study also considers the density of the social network which is the extent at which the authors (nodes) relates or interact with each other. The density varies from 0 to 1 meaning that when there is maximum interaction between the authors, it connotes 1 and 0 if otherwise which indicates that the more connected the nodes are, the higher the network density and the higher the interaction between the authors. A study of Accounting researchers from a worldclass Private University in Ogun State was conducted. There are 16 academic researchers (authors) in the department of Accounting out of which 12 was sampled constituting $75 \%$ of the population through the purposive sampling technique. The sample size consists of staff between the position of Lecturer 1 to Professor cadre. Data for the study was spooled from the individual google scholar platform which indicated the number of articles published on high impact journal outlets (Scopus index) and the collaborations between the authors from 2011 till date. The data obtained was analysed through Social Network Analysis (SNA) as well as Regression analysis method.

\section{Data Analysis}

The initial point of analysing the relationship between the authors is by converting all the relationship to 0 and 1 indicating that 1 when there exists relationship through coauthoring and 0 when no relationship exists thereby generating an adjacent matrix as follows:

Table 2. Adjacent matrix.

\begin{tabular}{lllllllllllll}
\hline $\mathbf{0}$ & $\mathbf{1}$ & $\mathbf{2}$ & $\mathbf{3}$ & $\mathbf{4}$ & $\mathbf{5}$ & $\mathbf{6}$ & $\mathbf{7}$ & $\mathbf{8}$ & $\mathbf{9}$ & $\mathbf{1 0}$ & $\mathbf{1 1}$ & $\mathbf{1 2}$ \\
\hline 1 & 1 & 1 & 1 & 1 & 1 & 1 & 1 & 1 & 0 & 0 & 1 & 1 \\
2 & 1 & 1 & 1 & 1 & 1 & 1 & 1 & 0 & 1 & 1 & 1 & 1 \\
3 & 1 & 1 & 1 & 0 & 1 & 1 & 1 & 0 & 1 & 1 & 1 & 0 \\
4 & 1 & 1 & 0 & 1 & 0 & 1 & 1 & 1 & 0 & 0 & 1 & 1 \\
5 & 1 & 1 & 1 & 0 & 1 & 1 & 1 & 0 & 0 & 0 & 1 & 0 \\
6 & 1 & 1 & 1 & 1 & 1 & 1 & 1 & 0 & 0 & 1 & 0 & 1 \\
7 & 1 & 1 & 1 & 1 & 1 & 1 & 1 & 1 & 0 & 0 & 1 & 1 \\
8 & 1 & 0 & 0 & 1 & 0 & 0 & 1 & 1 & 0 & 0 & 0 & 1 \\
9 & 0 & 1 & 1 & 0 & 0 & 0 & 0 & 0 & 1 & 1 & 0 & 0 \\
10 & 0 & 1 & 1 & 0 & 0 & 1 & 0 & 0 & 1 & 1 & 0 & 0 \\
11 & 1 & 1 & 1 & 1 & 1 & 0 & 1 & 0 & 0 & 0 & 1 & 1 \\
12 & 1 & 1 & 0 & 1 & 0 & 1 & 1 & 1 & 0 & 0 & 1 & 1 \\
\hline
\end{tabular}

Authors' compilation (2021). 


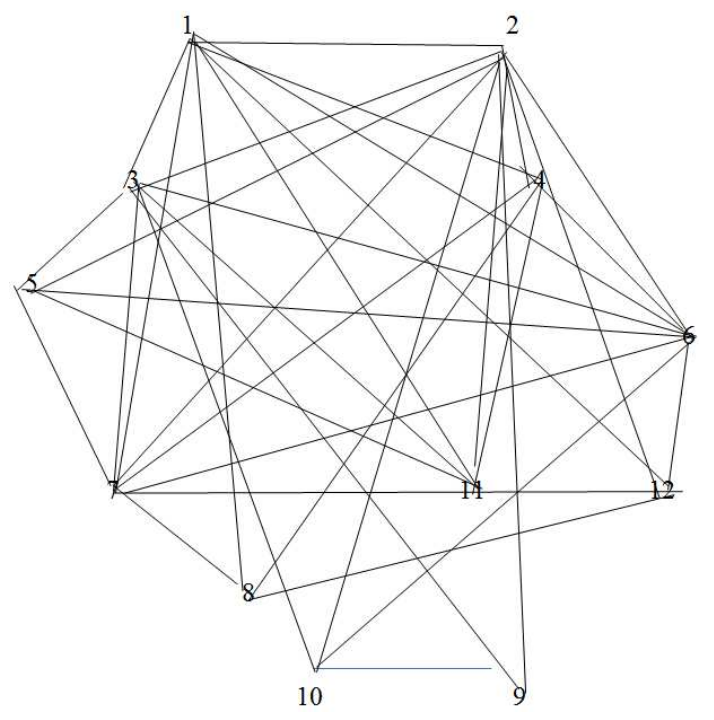

Figure 1. Authors, 2021.
From the table stated above, there 12 authors involved in the study and when relationship occurred between any two of them through co-authoring that symbolises (1) and otherwise (0).

From the illustration of social network analysis indicated above, it could be depicted that the social is densely related meaning that there exist high level of co-authorship and collaboration between the authors which resulted to quality number of articles published on high impact journals (Scopus index).

The table 2 above indicated the descriptive statistics of the study, the minimum number of articles published as well as collaborations existing between the is 0 while the maximum value is 108 for articles published and 1 for collaborations. The range is 108 for articles published while 1 for collaborations. The extent of variation represented by the standard deviation is 17.95 for articles published and 0.47775 for collaboration.

Table 3. Descriptive Statistics.

\begin{tabular}{|c|c|c|c|c|c|c|c|c|c|c|}
\hline & \multirow{2}{*}{$\mathbf{N}$} & \multirow{2}{*}{ Range } & \multirow{2}{*}{ Min } & \multirow{2}{*}{ Max } & \multirow{2}{*}{ Mean } & \multirow{2}{*}{ Std dev } & \multicolumn{2}{|c|}{ Skewness } & \multicolumn{2}{|c|}{ Kurtosis } \\
\hline & & & & & & & Stat & S. E & Stat & S. $\mathbf{E}$ \\
\hline Articles Published & 144 & 108 & 0 & 108 & 7.5069 & 17.95098 & 3.893 & 0.202 & 16.136 & 0.401 \\
\hline Collaborations & 144 & 1 & 0 & 1 & 0.6528 & 0.047775 & -0.65 & 0.202 & -1.602 & 0.401 \\
\hline Valid N & 144 & & & & & & & & & \\
\hline
\end{tabular}

Authors' compilation.

Table 4. ANOVA.

\begin{tabular}{lllll}
\hline Model & SS & Df & MS & F \\
\hline 1 Regression & 4316.493 & 1 & 4316.493 & 14.677 \\
Residual & 41736.5 & 142 & 294.109 & \\
Total & 46079.99 & 143 & & \\
a. Dependent Variable: ARTICLES PUBLISHED & & \\
b. Predictors: (Constant), COLLABORATIONS & & & \\
\hline
\end{tabular}

Authors' compilation, (2021).

From the table 3 above, the F-statistics is 14.677 with pvalue $=0.000<0.005$ which indicated a strong and positive relationship between collaborations and articles published. It reveals that the higher the collaborations the higher the articles published in high impact journals. The table indicated how the regression model is statistically significant as the pvalue is less than 0.05 at 0.000 the regression model is a good fit for the data.

The table 4 above indicated the best fit of the models adopted in the study. The R-square is a measure of statistics that indicated the extent of variation in the dependent variable explained by the variation in the independent variable. From the table 4 above the R-squared value is 0.094 which indicated that $9 \%$ variation in the articles published is as a result of $9.4 \%$ variation in the level of collaborations. The model is significant at $0.000<0.005$ while the value of 1.550 for Durbin Watson which is a sign of positive autocorrelation and fall within the acceptable region.

Table 5. Model Summary.

\begin{tabular}{|c|c|c|c|c|c|c|c|c|c|c|}
\hline \multirow{2}{*}{ Model } & \multirow{2}{*}{$\mathbf{R}$} & \multirow{2}{*}{ R Square } & \multirow{2}{*}{ Adj R Square } & \multirow{2}{*}{ S. E } & \multicolumn{5}{|c|}{ Change Statistics } & \multirow{2}{*}{$\begin{array}{l}\text { Durbin- } \\
\text { Watson }\end{array}$} \\
\hline & & & & & R Sq Change & F Change & df1 & df2 & Sig. F & \\
\hline 1 & $.306^{\mathrm{a}}$ & 0.094 & 0.087 & 17.15 & 0.094 & 14.677 & 1 & 140 & 0.000 & 1.550 \\
\hline
\end{tabular}

Predictors: (Constant), COLLABORATIONS

Dependent Variable: ARTICLES PUBLISHED

Authors' compilation, (2021).

From the table 5 above, the $\mathrm{t}$-value $=3.831$ and the $\mathrm{p}$-value indicated 0.000 which reveals a positive and strong relationship between authors; collaboration and the number and quality of articles published in the high impact journal.
The VIF of 1.000 is an indication of existence of multicollinearity when the VIF value is $>10$. However, from the study the VIF is $<10$ indicating absence of multicollinearity. 
Table 6. Coefficients ${ }^{a}$.

\begin{tabular}{|c|c|c|c|c|c|c|c|}
\hline \multirow{2}{*}{ Model } & \multicolumn{2}{|c|}{ Unstandardised Coeficients } & \multirow{2}{*}{$\begin{array}{l}\text { Stand. coeff. } \\
\text { Beta }\end{array}$} & \multirow{2}{*}{$\mathbf{T}$} & \multirow{2}{*}{ Sig. } & \multicolumn{2}{|c|}{ Collinearity Statistics } \\
\hline & B & Std. Error & & & & Tolerance & VIF \\
\hline (Constant) & $-2.42 \mathrm{E}-15$ & 2.425 & & 0.000 & 1.000 & & \\
\hline COLLABORATIONS & 11.5 & 3.002 & 0.306 & 3.831 & 0.000 & 1.000 & 1.000 \\
\hline
\end{tabular}

Authors' compilation, (2021).

Table 7. Correlation Statistics.

\begin{tabular}{lll}
\hline & ARTICLES PUBLISHED & COLLABORATIONS \\
\hline ARTICLES PUBLISHED & 1 & 0.845 \\
Sig (2-tailed) & & 0.000 \\
$\mathrm{~N}$ & 144 & 144 \\
COLLABORATIONS & 0.845 & 1 \\
Sig (2-tailed) & 0.000 & 144 \\
$\mathrm{~N}$ & 144 & \\
$* *$. Correlation is significant at the 0.01 level (2-tailed). & & \\
\hline
\end{tabular}

Authors' compilation, (2021).

Correlation statistics is an indication of relationship between variables. From table 5 above, the level of significance between the variables 0.000 with correlation coefficient $r=0.845$ positive and strong correlation between authors' collaborations and number as well as quality of articles published in high impact journal outlet.

\section{Discussions}

From the analysis presented above, it could be depicted that a positive and a strong relationship exist between authors' collaboration and the quality as well as number of articles published in high impact journals (Scopus index) as established by the study of [58] which stated that the mean number of articles across all discipline of accounting and management sciences published in high impact journals has increased due to harmonised skills which enhance the rate of manuscript acceptability in high impact journals as enunciated by [50]. For universities that are yet to involve actively in collaboration through sharing of individual pool of knowledge are greatly lacking behind in global visibility, enhanced articles in high rated journals as well affecting the global ranking of such institutions. The study of [64] revealed that sharing of knowledge between improves skill, and value the treasure of knowledge of researchers. Also supported is the view of [14] that posited that the universal movement of knowledge sharing improves research and development in all spheres which enhance collaborations as well as association between the researchers

\section{Conclusions and Recommendations}

It could be established from the study that effective collaborations between researchers improves knowledge sharing, skills and values. The study also established the fact that collaboration improves global visibility of researchers as well as University world ranking. Universities that are yet to embrace this might find themselves at the very tail region when compare to other counterpart. Therefore, the study suggested that Universities should engage in learning curve with their academia on how to improve learning, skills, knowledge sharing, global visibility through enhanced research collaborations.

\section{References}

[1] Acedo, F. J., Barroso, C., Casanueva, C., \& Galán, J. L. (2006). Co-authorship in management and organizational studies: An empirical and network analysis. Journal of Management Studies, 43, 957-983. https://doi.org/10.1111/j.1467-6486.2006.00625.x

[2] Aina, L. O. 2004. Library and information science text for Africa. Ibadan: Third World Information Services Ltd.

[3] Amabile, T. M., Patterson, C., Mueller, J., Wojcik, T., Odomirok, P. W., Marsh, M. and Kramer, S. J. 2001. Academicpractitioner collaboration in management research: a case of cross-profession collaboration. The Academy of Management Journal, 44 (2): 418-431.

[4] Aobdia, D. (2015). Proprietary information spillovers and supplier choice: evidence from auditors. Review of Accounting Studies, 20 (4), 1504-1539.

[5] Banjo, A. 2000. In the saddle: a vice chancellor's story. In The dilemma of post-colonial universities. Y. Lebeau and $\mathrm{M}$. Ogunsanya, Eds. Ibadan: IFRA/African Book Builders.

[6] Baek, E. C., Porter, M. A. \& Carolyn, P. (2020). Social network analysis for social neuroscientists. Social Cognitive and Affective Neuroscience, 2020, 1-19.

[7] Behara, R. S., Babbar, S., \& Smart, P. A. (2014). Leadership in OM research: A social network analysis of European researchers. International Journal of Operations and Production Management, 34, 1537-1563. https://doi.org/10.1108/IJOPM-08-2013-0390

[8] Benjamin, S. A. 2001. Perspective on university autonomy and the sustainability of higher education in Nigeria. 12th General Assembly of the Social Science Academy of Nigeria. 3-7 July 2001. Abuja. 21-28.

[9] Bianchi, P. A. (2018). Auditors' Joint Engagements and Audit Quality: Evidence from Italian Private Companies. Contemporary Accounting Research, 35 (3), 1533-1577. 
[10] Bianchi, P. A., Carrera, N. \& Trombetta M. (2020). The effect of auditor social and human capital on auditor compensation: Evidence from the Italian small audit firm market. European Accounting Review 29 (3), 693-721.

[11] Bills, K. L., C. Hayne, and S. E. Stein. (2018). A Field Study on Small Accounting Firm Membership in Associations and Networks: Implications for Audit Quality. The Accounting Review, 93 (5), 73-96.

[12] Boydell, L. R. and Rugkåsa, J. 2007. Benefits of working in partnership: a model. Critical Public Health, 17 (3): 217-228.

[13] Brass, D. J. (1995). A social network perspective on human resources management. Research in Personnel and Human Resources Management, 13, 39-79.

[14] Britz, J. J. and Ponelis, S. 2012. Social justice and the international flow of knowledge with specific reference to African scholars. Aslib Proceedings, 64 (5): 462-477.

[15] Causholli, M., T. Floyd, N. T. Jenkins, and S. M. Soltis. (2020). The ties that bind: Knowledge seeking networks and auditor job performance. SSRN Working Paper Series, 1-62.

[16] Coleman, J. S. (1988). Social capital in the creation of human capital. American Journal of Sociology 94 (Supplement), 95-120.

[17] Corley, E. A., \& Sabharwal, M. (2010). Scholarly collaboration and productivity patterns in public administration: Analysing recent trends. Public Administration, 88, 627-648. https://doi.org/ 10.1111/j.14679299.2010. 01830.x

[18] Crane, D. 1972. Invisible college: diffusion of knowledge in scientific communities. Chicago, University of Chicago Press.

[19] Crossley, N., Belloti, E., Edwards, G., Everett, M. G., Koskinen, J. H., Tranmer, M. (2015). Social Network Analysis for Ego-Nets, Thousand Oaks, CA: SAGE Publications.

[20] Cruz, A. P. C., Espejo, M. M. S. B., Costa, F., \& Almeida, L. B. (2011). Profile of scientific cooperation networks: USP Congress of Controllership and Accounting - 2001 to 2009. Accounting and Finance Magazine 22, 64-87. http://dx.doi.org/10.1590/S1519-70772011000100005

[21] Davison, A. G., Stening, B. W., \& Wai, W. T (1984). Auditor Concentration and the impact of interlocking directorates. Journal of Accounting Research 22 (1), 313-317.

[22] De Bruyn, Arnaud and Gary L. Lilien. (2008). A Multi-stage Model of Word-of-Mouth Influence through Viral Marketing. Inter. J. Res. in Marketing. 25 (3) 151-163.

[23] Dechow, P. M., and S. T. Tan. (2020). How Do Accounting Practices Spread? An Examination of Law Firm Networks and Stock Option Backdating. The Accounting Review, Forthcoming.

[24] DeFond, M., J. \& Zang, J. (2014). A review of archival auditing research. Journal of Accounting and Economics, 58 (2-3), 275-326.

[25] Dias, A., Ruthes, S., Lima, L., Campra, E., Siva, M. \& Porto, G. (2019). Network centrality analysis in Management and Accounting sciences. www.emeraldinsight.com/2531-0488.htm.

[26] Endenich, C., \& Trapp, R. (2016). Cooperation for publication? An analysis of co-authorship patterns in leading accounting journals. European Accounting Review, 25, 613633. https://doi.org/10.1080/ 09638180.2015.1085886
[27] Espartel, L. B., Basso, K., Callegaro, A. R. C., Visentini, M. S., Tomazelli, J. B., \& Henderson-Errandonea, V. M. (2013). Scientific collaboration in management: analysis of publications in co-authorship in Brazil among 2000-2010]. Organisational Management Magazine, 6, 77-92.

[28] Euske, K. J., Hesford, J., Malina, M. A. (2011). A social network analysis of the literature on Management Control. Journal of Management Accounting Research. 23, 259-283.

[29] Ferreira, M. P. V., Canela, R., Pinto, C. F., \& Falaster, C. D. (2018). Co-authorship in management in Brazil: pressures, complementarities and productivity. BASE - Unisinos Administration and Accounting Magazine 15, 42-55. https://doi.org/10.4013/base.2018.151.04

[30] Francis, J. R., and P. N. Michas, (2013). The Contagion Effect of Low-Quality Audits. The Accounting Review, 88 (2), 521552.

[31] Francis, J. R., Mehta, M. N. \& Zhao, W. (2017). Audit office reputation shocks from gains and losses of majority industry clients. Contemporary Accounting Research 34 (4), 1922-1974.

[32] Freeman, L. C. (2004). The development of SNA. A study in the sociology of science. Empirical press, Vancouver, BC Canada.

[33] Furstenau, L. B., Rabaioli, B., Sott, M. K., Cossul, D., Bender, M. S., Farina, E. M. J. D. M., F ilho, F. N. B., Severo, P. P., Dohan, M. S., Brazazzi, N. L. (2021). A Bibliometric network analysis of coronavirus during the first Eight Months of covid19 in 2020. International Journal of Environmental Research and Public Health 2021, (18), 952, 1-24. https://doi.org/10.3390/ijerph18030952.

[34] Gamble, T. K. 2002. Communication Works. New York. McGraw-Hill Companies.

[35] Gilly, M. C., Graham, J. L., Wolfinbarger, M. F. \& Yale, L. J. (1998) A dyadic study of interpersonal information search. Journal of the Academy of Marketing Science, 26 (2), pp. 83 100.

[36] Guan, Y., L. N. Su, D. Wu, and Z. Yang. (2016). Do school ties between auditors and client executives influence audit outcomes? Journal of Accounting and Economics, 61 (2-3), 506-525.

[37] Grunspan, D. Z., Wiggins, B. L., \& Goodreau, S. M. (2014). Understanding classrooms through social network analysis: A primer for social network analysis in Education research. CBE - Life Sciences Education 13 (2014), 167-178.

[38] Hannah, R. L. 1998. Merging the intellectual and technical infrastructures in higher education: the internet example. The Internet and Higher Education, 1 (1): 7-20.

[39] He, X., J. A. Pittman, O. M. Rui, and D. Wu. (2017). Do Social Ties between External Auditors and Audit Committee Members Affect Audit Quality? The Accounting Review, 92 (5), 61-87.

[40] Heider, F. (1958). The Psychology of Interpersonal Relation. John Wiley \& Sons.

[41] Hogg, M. A., \& Terry, D. J. (2000). Social identity and selfcategorization processes in organizational contexts. Academy of Ma.

[42] Jha, A. \& Chen, Y. (2015). Audit fees and social capital. The Accounting Review 90 (2), 611-639. 
[43] Jones, K. S. 2006. Giving and volunteering as distinct forms of civic engagement: the role of community integration and personal resources in formal helping. Non-profit and Voluntary Sector Quarterly, 35 (2): 249-266.

[44] Kacanski, S. \& Lusher, D. (2017). The application of Social Network Analysis to Accounting and Auditing. International Journal of Academic Research in Accounting, Finance and Management Sciences. 7 (3), 182-197.

[45] Katz, N., Lazer, D., Arrow, H., \& Contractor, N. S. (2004). Applying a network perspective to small groups: Theory and research. In M. S. Poole \& A. B. Hollingshead (Eds.), Theories of small groups: An interdisciplinary perspective. Newbury Park, CA: Sage.

[46] Knoke, D.(1994). "Networks of Elite Structure and DecisionMaking." Pp. 274-94 in Advances in Social Network Analysis: Research in the Social and Behavioral Sciences.

[47] Koseoglu, M. A. (2016). Mapping the institutional collaboration network of strategic management research: 1980-2014. Scientometrics, 109, 203-226. https://doi.org/10.1007/s11192-016-1894-5

[48] Lasker, R. D. and Weiss, E. S. 2003. Creating partnership synergy: the critical role of community stakeholders. Journal of Health and Human Services Administration, 26 (1): 119139.

[49] Lazarsfeld, P. F. \& Merton, R. K. (1954) "Friendship as a Social Process: A Substantive and Methodological Analysis." In Social Control, the Group, and the Individual eds Morroe Berger, Theodore Abel, and Charles H. Page. New York: D. Van Nostrand Company, Inc..

[50] Liu, C., Olivola, C. Y. \& Kovacs, B. (2017). Co-authorship trend in the field of management: Facts and Perceptions. Academy of Management Learning and Education 16, 509530. https://doi.org/10.5465/amle.2016.0080

[51] Markus, M. L. (1987) Toward a "critical mass" theory of interactive media. Common Res 14 (5): 491-511. doi: $10.1177 / 009365087014005003$.

[52] Marsden, P. V., \& Campbell K. E. (1984). Measuring tiestrength. Social Forces, 63: 482-501.

[53] Marwell, G., \& Oliver, P. (1998). The critical mass in collective action: A micro-social theory. Cambridge, MA: Cambridge University Press.

[54] McPherson, M., Smith-Lovin, L. \& Cook, J. M. (2001) Birds of a feather: homophily in social networks. Annual Review of Sociology, 27 (1), pp. 415-444.

[55] Nelson, R. R. 2004. The market economy and the scientific commons. Research Policy, 33: 455-471.

[56] Newman, M. E. J. 2000. The structure of scientific collaboration networks. PNAS, 98 (2): 404-409. DOI: 10.1073/pnas.98.2.404.

[57] Nielsen, M. W. (2017). Gender and citation impact in management research. Journal of Informetrics, 11, 1213-1228. http://dx.doi.org/10.1016/j.joi.2017.09.005

[58] Nikzad, M., Jamali, H. R., \& Hariri, N. (2011). Patterns of Iranian co-authorship networks in social sciences: A comparative study. Library and Information Science Research, 33, 313-319. https:// doi.org/10.1016/j.lisr.2011.01.005
[59] Nunes, M. \& Abreu, A. (2020). Applying social network analysis to identify project critical success factor. Sustainability 2020 (12), 1-32. Doi: 10.3390/su12041503.

[60] Orozco, L. A., \& Villaveces, J. L. (2015). Heterogeneous research networks in Latin American schools of business management. Academia Latin American Journal of Administration 28, 115-134. https://doi.org/10.1108/ARLA05-2013-0052

[61] Pacheco, G. G., Pinedo, R. D. Y., Ditta, A., Ruiz, M., \& Varela, A. (2018). Gender difference in publication among recent or/MS scientific publications in top journals. Spaces, $39,20-33$.

[62] Rafaeli S., LaRose R. J. (1993). Electronic Bulletin Boards and 'Public Goods'Explanations of Collective Mass Media. Communication Research, 20, 277-97.

[63] Rice. R. E., August G., Joseph S. and Jack. (1990) Individual and network influence on the adoption and perceived outcomes of electronic messaging. Social Networks 12: 27 -. X'S.

[64] Riege, A. 2005. Three-dozen knowledge sharing barriers managers must consider. Journal of Knowledge Management, $9(3): 18-35$.

[65] Ronda-Pupo, G. A., Díaz-Contreras, C., Ronda-Velázquez, G., \& Ronda-Pupo, J. C. (2015). The role of academic collaboration in the impact of Latin-American research on management. Scientometrics, 102, 1435-1454. https://doi.org/10.1007/s11192-014-1486-1

[66] Rossoni, L., \& Guarido Filho, E. R. (2007). Interinstitutional cooperation in the field of strategy research [Interinstitutional cooperation in the research field of strategy]. Business Administration Magazine, 47, 74-88. http://dx.doi.org/10.1590/S0034-75902007000400007

[67] Salter, B. (1983). Contract research: universities and the knowledge market. Higher Education Review, 15.

[68] Sani, A. F \& Ocholla. D. (2015). Comparative assessment of information and knowledge sharing among academics in selected universities in Nigeria and South Africa. Journal of Library and Information Sciences 201581 (1).

[69] Saqr, M. \& Alamro, A. (2019). The role of social network analysis as a learning analytics tool in online problem-based learning. BMC Medical Education (2019) 19: 160, 1-11. https://doi.org/10.1186/s12909-019-1599-6.

[70] Senthilnathan, S. (2020). Network Analysis Part 1 - An introductory part.

[71] Shah, N. P., A. Parker, and C. Waldstrom. (2017). Examining the overlap: Individual performance benefits of multiplex relationships. Management Communication Quarterly 31 (1): $5-18$.

[72] Sheedy, C. (2019). Social network analysis, what it is and how it matters. https://www.intheblack.com/articles/2019/12/01/what-issocial-network-analysis

[73] Sidone, O. J. G., Haddah, E. A., Mena-Chalco, J. P. (2016). Science in Brazilian regions: development of scholarly production and research collaborations network. Transinformacao 28, 15.31. http://dx.doi.org/10.1590/231808892016002800002 . 
[74] Sonnenwald, D. H. and Liewrouw, L. A. 1997. Collaboration during the design process: a case study of communication, information behaviour, and project performance. In Information seeking in context: proceedings of an international conference on research in information needs, seeking and use in different contexts. P. Vakkari, R. Savolainen and B. Dervin, Eds. London: Taylor Graham. 179204.

[75] Stoan, S. K. 1991. Research and information retrieval among academic researchers: implication for library instruction. Library Trends, 39 (3): 238-257.
[76] Tajfel, H., Flament, C., Billig, M., \& Bundy, R. (1971). Social categorization and intergorup behavior. European Journal of Social Psychology, 1, 149-178.

[77] Wood, T. Jr. \& Chueke, G. V. (2008). Ranking of scientific production in business administration in Brazil. Ram Manckezie Administration Magazine 9, 13-31. http://dx.doi.org/10.1590/S1678.69712008000400003.

[78] Worrell, J., Wasko, M., \& Johnston, A. (2013). Social network analysis in accounting information systems research. International Journal of Accounting Information Systems 14 (2013), 127-137. 